\title{
PRINSIP TANGGUNGJAWAB KOMANDAN DALAM PERSPEKTIF HUKUM PIDANA ISLAM (JINAYAH)
}

\author{
Ria Wulandari \\ Email: ria.wulandari1979@gmail.com
}

\begin{abstract}
Article 28 (a.1) of the Rome Statute of the International Criminal Court 1998 states that the commander shall be criminally responsible for crime if it meets the element of knowing or should know that his troops were commiting or about to commit a crime. This is different for civilian officials or superiors who are only criminally responsible for crime if the superiors either knew, or consciously disregarded information which clearly indicated, that the sobrodinates were commiting or about to commit such crimes (article 28 (b.1). These two rule differences (for commanders and civil officials) are believed to be article 28 has weakened the power of dolus and culpa elements or even ignorance of subordinate crimes. It is necessary to see the provisions of the commander's responsibility from the perspective of Islamic criminal law which may differ from both the element and punishment. This paper highlighted the genocide crime. Genocide means any of the following acts committed with intent to destroy, in whole or in part, a national, ethnical, racial or religious groups (article 6 of the Rome Statute of 1998). The Islamic criminal law does not govern the genocide but has regulated punishment for the person who ordered the criminal acts (murder) as well as punishment for acts committed intentionally or unintentionally. From the existing principles of Islamic criminal law can be drawn a legal argument about punishment for the commander in which his forces committed a genocida crime.
\end{abstract}

Keywords: Responsibility of Commander, Islam Criminal Law (Jinayah).

\begin{abstract}
Abstrak
Pasal 28 (a.1) Statuta Roma 1998 menyebutkan bahwa komandan bertanggungjawab secara pidana jika memenuhi unsur mengetahui atau seharusnya mengetahui bahwa pasukannya melakukan suatu tindak pidana. Hal ini berbeda untuk pejabat sipil atau atasan dimana yang dikenakan tanggungjawab pidana hanya yang mengetahui atau secara sadar tidak menghiraukan informasi bawahan yang melakukan tindak pidana (pasal 28 (b.1). Dari kedua perbedaan aturan (untuk komandan dan pejabat sipil) diyakini pasal 28 telah melemahkan kekuatan elemen dolus (kesengajaan) dan culpa (kelalaian) atau bahkan tidak mengetahui sama sekali kejahatan bawahan. Perlu kiranya melihat ketentuan mengenai pertanggungjawaban komandan dari perspektif hukum pidana Islam yang kemungkinan memiliki perbedaan baik dari unsur maupun penghukumannya. Penghukuman tindak pidana yang disorot dalam tulisan ini adalah genocida. Genocida adalah perbuatan yang dilakukan dengan maksud untuk menghancurkan atau memusnahkan seluruh atau sebagian kelompok bangsa, ras, kelompok etnis, kelompok agama(pasal 6 Statuta Roma tahun 1998). Hukum Pidana Islam tidak mengatur mengenai genocida namun telah mengatur hukuman bagi orang yang menyuruh melakukan perbuatan pidana (pembunuhan) serta hukuman bagi perbuatan yang dilakukan dengan sengaja atau tidak sengaja. Dari asas-asas Hukum Pidana Islam yang telah ada dapat ditarik suatu argument hukum tentang hukuman bagi komandan yang mana pasukannya melakukan tindak pidana genocida.
\end{abstract}

Kata Kunci : Tanggungjawab Komandan, Hukum Pidana Islam (Jinayah), Genocida. 


\section{Pendahuluan}

Mahkamah Pidana Internasional (International Criminal Court) adalah sebuah sejarah baru dalam gerakan hak asasi manusia karena peradilan ini memiliki kewenangan untuk mengadili para pelaku (individu) pelanggar hak asasi manusia. Hal ini berbeda dengan peradilan yang telah ada yakni Mahkamah Internasional (International Court of Justice/ICJ) yang hanya dapat mengadili Negara.

Dengan dapat di adilinya individu ke Mahkamah Pidana Internasioal dalam Statuta Roma telah membuka babak baru dalam hukum internasional yang pasti akan mempengaruhi prilaku Negara sekaligus prilaku manusia ${ }^{1}$ karena pada saat itu seorang individu untuk pertama kalinya masuk dalam jangkauan hukum internasional yang harus memikul pertanggungjawaban pidana secara pribadi atas apa yang sebelumnya dianggap sebagai pertanggungjawaban yang harus dipikul Negara. Pada saat itu pula mahkamah menutup mata terhadap kedudukan individu sebagai pejabat Negara atau personel militer dalam penjatuhan pidana.

Tindak pidana yang diatur dalam Statuta Roma tahun 1998 merupakan jenis tindak pidana baru yang bersifat luar biasa dan belum dikenal secara luas. ${ }^{2}$ Yurisdiksi Mahkamah Pidana Internasional difokuskan pada kejahatan sangat serius yang melibatkan tindak pidana genocida (pembunuhan massal), kejahatan terhadap kemanusiaan, kejahatan perang dan kejahatan agresi. Selain difokuskan pada jenis tindak pidana yang serius (meliputi empat tindak pidana diatas) Mahkamah Pidana Internasional juga fokus pada pelaku. Pelaku utama maupun pembantu tindak pidana dapat diadili di Mahkamah Pidana Internasional.

\footnotetext{
${ }^{1}$ Todung Mulya Lubis,Jalan Panjang Hak Asasi Manusia, (Jakarta: PT Gramedia Pustaka Utama, 2005). 3

${ }^{2}$ Romli Atmasasmita,Karakteristik Tindak Pidana Dalam Statuta ICC Dan Dampak Pembentukan Pengadilan Pidana Internasional Terhadap Perkembangan Hukum Pidana, Jurnal Hukum Internasional, Volume 4, bulan Oktober 2006, (Jakarta:Lembaga Pengkajian Hukum Internasional,Fakultas Hukum Universitas Indonesia). 63
} 
Tindak pidana yang tercantum dalam Mahkamah Pidana Internasional merupakan tindak pidana sangat serius yang diakui menurut masyarakat internasional secara keseluruhan. Oleh karena itu perlu ada penuntutan yang efektif yang dijamin dengan pengambilan tindakan ditingkat nasional melalui kerjasama internasional.

Meskipun Indonesia belum meratifikasi Statuta Roma tahun 1998 sebagai dasar lahirnya Mahkamah Pidana Internasional, namun Indonesia telah mengadopsi jenis tindak pidana yang tercantum dalamMahkamah Pidana Internasional berikut para pelaku tindak pidana tersebut yang terrmuat dalam Undang-Undang N0 26 tahun 2000 tentang Pengadilan Hak Asasi Manusia.

Namun tidak semua pelaku tindak pidana tersebut dapat diadili di Mahkamah Pidana Internasional. Pengadilan ini hanya mengadili orang-orang yang paling bertanggung jawab (Those who bear the greatest responsibility) atas terjadinya suatu tindak pidana. ${ }^{3} \mathrm{Hal}$ tersebut terlihat dalam Statuta Roma tahun 1998 yang mengenal tanggung jawab komandan atau atasan (untuk pemerintahan sipil). Dalam hal ini Mahkamah Pidana Internasional telah menanggalkan impunitas dari seorang komandan atau atasan dan memiliki yurisdiksi atas orang/individu yang bersangkutan dalam kedudukannya sebagai individu yang harus bertanggung jawab secara pidana. ${ }^{4}$

Di dalam pasal 28 Statuta Roma tahun 1998 memuat ketentuan yaitu pertama ketentuan untuk pejabat militer dan ketentuan untuk pejabat sipil (yang disebut dengan Atasan). Syarat-syarat pertanggungjawaban pimpinan atas perbuatan bawahannya juga berbeda antara tanggungjawab pejabat militer dan pejabat sipil. Pasal ini menyebutkan bahwa komandan bertanggungjawab secara pidana jika memenuhi unsur : pertama, mengetahui atau seharusnya mengetahui bahwa pasukannya melakukan tindak pidana. Hal ini berbeda untuk pejabat sipil (Atasan) dimana yang dikenakan tanggung jawab

\footnotetext{
${ }^{3}$ Aristo M.A.Pangaribuan,Perdebatan Menuju Mahkamah Pidana Internasional(International Criminal Court),(Jakarta;Papas Sinar Sinanti dan FHUI,2013). 139

${ }^{4}$ I Wayan Parthiana,Hukum Pidana Internasional, (Bandung;CV Yrama Widya,2006). 212
} 
pidana hanya yang mengetahui atau secara sadar tidak menghiraukan informasi mengenai bawahannya yang melakukan tindak pidana. Unsur yang kedua, bahwa komandan tersebut gagal melakukan segala tindakan yang diperlukan untuk mencegah kejahatan dan melaporkannya pada pihak yang berwenang untuk diadakan penyelidikan dan penuntutan (unsur yang kedua berlaku sama untuk atasan bagi pejabat sipil).

Implementasi ketentuan mengenai pertanggungjawaban komandan/atasan dalam pelanggaran HAM berat kedalam hukum nasional tidak sama karena adanya perbedaan sistem hukum (Civil Law dan Common Law) yang masih dianut di beberapa Negara. Sistem hukum yang dianut di Kanada menganut sistem hukum Common Law; dan dalam pandangan pemerintah Kanada, sistem pertanggungjawaban pidana komandan/atasan dalam pelanggaran HAM berat dengan menggunakan "Should have known test” (SHKnt) tidaklah adil dan cenderung merupakan stigmatisasi yang negatif. ${ }^{5}$ Pertanyaan mendasar yang dikemukakan pembentuk undang-undang di Kanada ialah, bahwa SHKnt tidak fair dan menyudutkan seorang komandan dan melemahkan kekuatan elemen Dolus (with intent $^{6}$ atau Culpa (negligence) ${ }^{7}$ yang sudah bersifat universal dan sudah lama dianut didalam sistem hukum pidana didunia. ${ }^{8}$ Pertanyaan kedua, bagaimana mungkin untuk suatu peristiwa pelanggaran HAM berat, diterapkan standar SHKnt yang telah menempatkan seorang komandan sebagai seseorang yang seharusnya bertanggungjawab

\footnotetext{
${ }^{5}$ Romli Atmasasmita,PengantarHukum Pidana Internasional Bagian II, (Jakarta;PT Hecca Mitra Utama,2004). 16

${ }^{6}$ Dolus atau kesengajaan, artinya perbuatan pidana itu memuat unsur kesengajaan..Secara umum para pakar hukum pidana telah menerima adanya tiga (3) bentuk kesengajaan yakni kesengajaan sebagai maksud, kesengajaan dengan kesadara pasti serta kesengajaan dengan kesadaran kemungkinan. Elemen dolus dalam tulisan ini menurut penulis adalah dolus dengan kesadaran kemungkinan yakni kesengajaan bersayarat yang bertolak dari kemungkinan. Artinya, tidak lebih banyak dikehendaki dan diketahui daripada kemungkinan itu. Misalnya, seseorang yang menghendaki kemungkinan matinya orang lain, tidak dapat dikatakan bahwa ia menghendaki supaya orang itu mati.

${ }^{7}$ Culpa atau kealpaan, artinya perbuatan pidana itu memuat unsur kealpaan. Menurut Prof.Dr.Wirjono Prodjodikoro,SH, dalam bukunya yang berjudul Asas-Asas Hukum Pidana di Indonesia . 72 mengatakan bahwa arti culpa adalah "kesalahan pada umumnya”, tetapi dalam ilmu pengetahuan hukum mempunyai arti teknis, yaitu suatu macam kesalahan si pelaku tindak pidana yang tidak seberat seperti kesengajaan yakni kurang berhati-hati sehingga akibat yang disengaja terjadi. Sementara Jan Remmelink menyatakan bahwa culpa berarti tidak atau kurang menduga secara nyata (terlebih dahulu kemungkinan munculnya) akibat fatal dari tindakan orang tersebut, padahal itu mudah dilakukan dan karena itu seharusnya dilakukan.

${ }^{8}$ Ibid. 16
} 
atas suatu pelanggaran HAM berat sekalipun komandan tersebut tidak mengetahui sama sekali peristiwa tersebut dan tidak berada di locus delicti. ${ }^{9}$

Selain sistem hukum Civil Law dan Common Law, adapula sistem hukum Islam. Berdasarkan sejarah perkembangan agama Islam sejak nabi Muhammad pengaruhnya meluas sejak abad pertengahan di Asia dan Afrika Utara yang bersamaan waktunya dengan revolusi industri di Eropa, disamping itu hukum yang mengatur hubungan antar manusia sebagai hukum Islam, memiliki sistem hukum sendiri yang sejajar dengan sistem-sistem hukum lainnya. ${ }^{10}$

Didalam Hukum Pidana Islam, aspek keyakinan (dosa dan pahala), aspek moral, apa yang baik dan buruk, unsur latar belakang terjadinya suatu tindak pidana baik dari niat, lalai, sengaja, terpaksa serta sanksi yang memiliki daya preventive sekaligus repressive, menjadi satu kesatuan yang utuh didalam mencapai keadilan. Melihat segi historis dan kemajuan sistem hukum Islam maka perlu kiranya melihat ketentuan mengenai pertanggungjawaban komandan dari persepektif Hukum Pidana Islam yang kemungkinan memiliki perbedaan baik dari unsur-unsur maupun penghukumannya sebagai bahan perbandingan dengan ketentuan pertanggungjawaban komandan dalam Statuta Roma tahun 1998.

Berdasarkan uraian diatas, maka tulisan ini hendak mengkaji tentang "Bagaimanakah ketentuan pertanggungjawaban komandan dari perspektif Hukum Pidana umum dan Islam? Dan Bagaimanakah Hukuman Bagi Komandan Yang Terbukti Bersalah?”

\section{Pembahasan}

A. Ketentuan Tanggung Jawab Komandan Dalam Hukum Pidana Umum dan Islam

Didalam hukum internasional prinsip “mengadili orang yang paling bertanggung jawab dalam suatu tindak pidana internasional” merupakan prinsip yang baru. Orang yang

\footnotetext{
${ }^{9}$ Ibid

${ }^{10}$ Abdul Djamali,Hukum Islam, (Bandung;CV Mandar Maju,2002). 8
} 
paling bertanggung jawab dalam suatu tindak pidana internasional yang dimaksud disini adalah seorang komandan yang memberi perintah sehingga terjadilah suatu tindak pidana internasional. Sementara itu, didalam hukum nasional (dan hukum internasional klasik), seorang komandan memiliki impunitas dalam setiap keputusan-keputusannya. sejak berakhirnya perang dingin, ada gagasan untuk mengakhiri impunitas, namun gagasan ini sulit terealisasi karena selalu berbenturan dengan isu-isu nasionalisme dan kedaulatan Negara.

Setelah Perang Dunia II, para sekutu yang merupakan pemenang perang mendirikan suatu pengadilan yang khusus mengadili individu pelaku tindak pidana internasional. dasar pemikiran diadilinya individu adalah bahwa hukum internasional membebankan tugas dan kewajiban pada individu maupun pada Negara karena tindak pidana terhadap hukum internasional dilakukan oleh manusia, bukan oleh wujud yang abstrak dan hanya dengan menghukum individu yang melakukan tindak pidana tersebut ketentuan hukum internasional bisa ditegakkan. ${ }^{11}$

Prinsip tanggung jawab individu merupakan prinsip yang telah lama dikenal dalam hukum nasional dan telah diakui sebagai prinsip universal. Hans Kelsen dalam pendapatnya tentang tanggung jawab didalam hukum nasional membagi tanggung jawab menjadi tanggung jawab individu dan tanggung jawab kolektif. Menurut Kelsen, tanggung jawab individu adalah pada saat sanksi dikenakan hanya pada delinquent (pelaku) sedangkan tanggung jawab kolektif adalah ketika sanksi tidak atau tidak hanya dikenakan pada delinquent tetapi juga terhadap individu yang secara hukum terkait dengannya. Baik pertanggungjawaban individu maupun kolektif dapat diberlakukan mengingat fakta bahwa tidak ada individu dalam masyarakat yang sepenuhnya independen. $^{12}$ Didalam hukum internasional tidak dikenal pembedaan antara

\footnotetext{
${ }^{11}$ Malcolm.N.Shaw,QC,Hukum Internasional, (Bandung : Nusa Media,2013). 393

${ }^{12}$ Hans Kelsen,Teori Tentang hukum, (Jakarta:Konstitusi Pers,2012) . 58
} 
tanggungjawab individu maupun kolektif seperti yang dikemukakan Hans Kelsen, karena didalam hukum internasional tanggung jawab kolektif juga disebut tanggung jawab individu. Contoh tanggung jawab kolektif yang serupa dengan pengertian dari Hans Kelsen adalah seorang bawahan yang melakukan tindak pidana karena melaksanakan perintah atasan harus pula mempertanggungjawabkan perbuatannya. Jadi, baik yang memerintahkan atau yang melaksanakan suatu kejahatan harus mempertanggungjawabkan perbuatannya (pasal 28 dan 33 Statuta Roma) pertanggungjawaban yang demikian dalam hukum internasional disebut juga pertanggungjawaban individu.

Pertanggungjawaban Individual sebenarnya telah dikemukakan oleh Hugo Grotius sejak tahun 1625 dalam bukunya "De Jure Belli Ac Pacis Libri Tres (The Law of War and Peace In Three Books)”. Dalam bukunya tersebut, Grotius menegaskan bahwa sekalipun jenderal atau prajurit yang sesungguhnya dapat mencegah kejadian/ kerugian sepenuhnya dapat dipertanggungjawabkan atas tindakannya. ${ }^{13}$

Meski ide pertanggungjawaban secara individual telah muncul pada tahun 1625 namun baru pada tahun 2002 konsep ini mendapat tempatnya didalam Statuta Roma tahun 1998 yang menjadi hukum internasional positif bagi pembentukan Mahkamah Pidana Internasional yang sifatnya permanen. Tindak pidana yang merupakan yurisdiksi Mahkamah Pidana Internasional sebagaimana tercantum dalam pasal 5 Statuta Roma tahun 1998 antara lain : Genocida, kejahatan terhadap kemanusiaan, kejahatan perang dan kejahatan agresi. Hukuman bagi tindak pidana tersebut adalah pidana penjara paling lama 30 tahun, seumur hidup, denda dan penebusan hasil, kekayaan dan aset yang diperoleh langsung atau tidak langsung dari suatu tindak pidana (semua hukuman tersebut tergantung berat-ringannya tindak pidana). Tindak pidana genocida adalah tindak pidana yang dibahas dalam tulisan ini. Tindak pidana genocida merupakan Gross Violation of

\footnotetext{
${ }^{13}$ Romli Atmasasmita,Pengantar hukum Pidana Jilid I, (Bandung:PT Refika Aditama). 3
} 
Human Rights yang dikategorikan sebagai musuh umat manusia (hostis humanis generis) serta merupakan tindak pidana yang melanggar normajus cogens yakni norma hukum fundamental yang bersifat mengikat dan imperatif, universal, memiliki arti penting luar biasa serta merupakan bagian essential dalam sistem hukum internasional.Genocida telah dikatakan sebagai tindak pidana internasional karena dipandang sebagai ancaman secara langsung dan tidak langsung atas perdamaian dan keamanan dunia serta menggoyahkan perasaan kemanusiaan. Kedudukan genocide sebagai tindak pidana internasional bahkan telah melebihi kedudukan pembajakan yang telah lebih dahulu diakui oleh masyarakat internasional. Genocida dianggap memiliki kandungan unsure yang bersifat penting jika dibandingkan dengan pembajakan yang memiliki kandungan yang bersifat berpotensi penting.

Adapun pengertian genocida menurut pasal 6 Statuta Roma tahun 1998adalah"14"perbuatan yang dilakukan dengan maksud untuk menghancurkan atau memusnahkan seluruh atau sebagian kelompok bangsa, ras, kelompok etnis, kelompok agama dengan cara :

1. Membunuh anggota kelompok;

2. Mengakibatkan penderitaan fisik atau mental yang berat terhadap anggotaanggota kelompok;

3. Menciptakan kondisi kehidupan kelompok yang akan mengakibatkan kemusnahan secara fisik baik seluruh atau sebagiannya;

4. Memaksakan tindakan-tindakan yang bertujuan mencegah kelahiran didalam kelompok; atau

5. Memindahkan secara paksa anak-anak dari kelompok tertentu ke kelompok lain.

\footnotetext{
${ }^{14}$ Ketentuan yang sama telah diadopsi dalam Undang-Undang No 26 tahun 2000 tentang Pengadilan Hak Asasi Manusia
} 
Tanggungjawab komandan tercantum dalam Statuta Roma tahun 1998 pasal 28 (a.1) dimana terdapat kata-kata "mengetahui atau seharusnya mengetahui" bahwa pasukannya melakukan tindak pidana. Hal ini berbeda dengan tanggungjawab atasan untuk sipil dalamStatuta Roma tahun 1998 pasal 28 (b.1) yang hanya "mengetahui atau secara sadar tidak menghiraukan” informasi mengenai bawahannya yang melakukan tindak pidana. Dari kedua pasal tersebut tergambar bahwapasal 28 (a.1)telah mengeyampingkan unsur dolus dan culpa sementara pasal 28 (b.1) hanya untuk perbuatan yang disengaja artinya pasal ini tetap memperhatikan unsur dolus dan culpa sebagai unsur universal dalam hukum pidana. Di dalam KUHP misalnya, penghukuman ketentuan mengenai pembunuhan (konvensional) secara sengaja dikenakan hukuman paling lama lima belas tahun penjara (pasal 338), sementara pasal lain juga menyebutkan perbuatan yang mengakibatkan matinya orang lain karena ketidaksengajaan/lalai dikenakan hukuman paling lama lima tahun penjara (pasal 359).

Hukum Islam merupakan hukum yang diturunkan Allah SWT kepada nabi Muhammad SAW yang bertujuan memberi keadilan pada seluruh umat manusia dan khususnya pada masyarakat arab yang pada masa itu berada masa jahiliyah yakni masa dimana terjadi kesewenang-wenangan dari penguasa dan kebodohan pada masyarakatnya sehingga tidak ada ketertiban dan keadilan pada masyarakat tersebut.

Hampir semua segi kehidupan diatur dalam Hukum Islam termasuk mengenai tindak pidana. Hukum mengenai tindak pidana ini dikenal dengan nama Jinayat yang secara etimologi diartikanmemetik, memotong, mengambil dan atau memungut sedangkan menurut agamakata jinayat berarti pelanggaran yang dilakukan oleh seseorang atau sekelompok orang dalam mengambil hak Allah, hak sesama manusia dan hak mahluk lainnya, yang atas perbuatannya dikehendaki ada pembalasan seimbang dunia akhirat dengan mendapat hukuman berat dari 
Allah. ${ }^{15}$ Yang dimaksud dengan mengambil hak Allah menurut Abdul Djamali adalah suatu perbuatan yang dilakukan oleh seseorang atau sekelompok orang dengan mengingkari segala kewajiban atas perintah Allah dan perbuatan itu berupa menghilangkan nyawa orang atas kehendaknya yang dinamakan pembunuhan. Atas perbuatannya tersebut mengakibatkan kematian orang lain yang kematiannya ini dianggap bukan kehendak Allah atau disebut juga mengambil hak Allah. Terhadap pelaku pembunuhan maka Hukum Pidana Islam menerapkan sanksi yang tegas berdasarkan niat pelaku karena Hukum Pidana Islam menetapkan faktor niat sebagai hal yang sangat menentukan berat ringannya sanksi hukum yang akan diterima pelaku pembunuhan. Mengenai niat bahkan ditegaskan oleh Nabi Muhammad Saw sebagaimana diriwayatkan Bukhori “Innamal 'a'maalu bi niyaati”(sesungguhnya setiap perbuatan (dilihat) berdasarkan niatnya).Terhadap pembunuhan yamg sengaja dilakukan ini ketentuan pasal hukumnya tercantum dalam :

Surah(4) An-Nisa ayat 93 menyatakan : “Wa man yaqtul mu'minan muta’ammidan fajazaaauhu jahannamu kholidan fiiha wa ghodiballaohu 'alaihi wala'anahuu wa a'addalahu 'adjaaban 'adziimaa” ("Barangsiapa membunuh orang mukmin dengan sengaja, maka balasannya ialah neraka untuk selama-lamanya, Allah murka kepadanya, dikutuknya dan disediakan siksa yang berat”).

Surah (2) Al-Baqarah ayat 178 menyatakan: "Yaa ayyuhalladjiina aamanuu kitabu 'alaikumul qisoosu fil qotlaa al hurrubil hurri wal "abdu bil "abdi wal untsaa bil untsaa. Fa man "ufiya lahuu min akhiihi syai un fattiba'un bil ma'ruuf wa adaa un ilaihi bil ihsan. Djaalika takhfiifu mirrobbikum wa rohmat. Famani’tada ba'da djaalika falahuu adjaabun aliim”.(“Hai orangorang yang beriman diwajibkan atas kamu melakukan qisas (balasan yang sama dengan perbuatannya) karena membunuh orang”).

${ }^{15}$ Op.cit,AbdulJamali. 190 
Sementara untuk pembunuhan yang dengan tidak ada kehendak kesengajaan, melakukan perbuatan menyakiti orang seperti memukul yang mengakibatkan kematian. Dalam hukum positif perbuatan ini dikenal sebagai Penganiayaan berat yang berakibat kematian. Hukuman bagi pelakunya tidak diwajibkan qisas ${ }^{16}$ melainkan wajib membayar diyat/denda berat ${ }^{17}$ yang pelaksanaannya dapat diangsur selama tiga (3) tahun kepada keluarga korban.

Kemudian suatu perbuatan yang dilakukan tanpa ada niat sama sekali untuk membunuh. Terhadap pembunuhan tidak sengaja ini sanksi qisasnya tidak wajib melainkan diwajibkan membayar "diyat ringan”"18 dan pembayaran diyat ringan itu dilakukan dengan memberi sesuatu kepada ahli waris korban dalam jumlah yang telah ditentukan.

Pasal hukum pembayaran diyat tercantum dalam surah (4) An-Nisa ayat 92 yang menyatakan :“Wa ma kaana li mu'minin ayyaqtula mu'minan illa khoto a wa man qotala mukminan khoto an fatahriiru qobatin mukminatin wa diyatun musallamatun ilaa ahlihii illaa ayyasshoddaqu fa inkaana min qaumin 'aduwwillakum wahuwa mukminun fatahriiru qobatin mukminat. Wainkaana min qaumin bainakum wa bainahum miitsaqun fadiibat mussalamat ilaa ahlihii wa tahriiruro qobatin mukminat faman lam yajid fashiyam syaroyni mutatabi'ain. Taubatan minalloh. Wa kaanallohu ‘aliiman hakiiman”.(“Dan tidak layak bagi seorang mukmin

16 Qisas Adalah hukuman bagi tindak pidana yang terjadi antara perorangan atau beberapa orang sehingga hukumannya menjadi hak perorangan (keluarga korban) sehingga membuka kesempatan pemaafan (dari keluarga korban) bagi pelaku tindak pidana. Qisas menurut arti katanya adalah akibat yang sama yang dikenakan kepada orang yang dengan sengaja menghilangkan jiwa atau melukai atau menghilangkan anggota badan orang lain.

${ }^{17}$ diyat adalah denda pengganti jiwa tanpa menjalankan hukuman mati. Pasal mengenai diyat tercantum dalam :

Hadist Nabi Muhammad Saw yang diriwayatkan oleh Turmidji : "Barangsiapa membunuh orang dengan sengaja, ia diserahkan kepada keluarga yang terbunuh, mereka boleh membunuhnya atau menarik denda”. Diyat terbagi menjadi dua yaitu diyat berat dan diyat ringan. Diyat Berat adalah Wajib bagi pelaku pembunuhan yang disengaja sebagai pengganti qisas karena memperoleh pengampunan yang dilakukan dengan membayar tunai sejumlah hewan yang telah ditetapkan. Banyaknya hewan yang wajib dibayar sejumlah 100 ekor unta terdiri dari 30 ekor unta betina berumur 3 jalan 4 tahun, 30 ekor unta betina berumur 4 jalan 5 tahun, dan 40 ekor unta betina dalam keadaan bunting. Jumlah hewan ini dibayarkan secara tunai.

\footnotetext{
${ }^{18}$ Diyat Ringan adalah Wajib dilakukan setiap pelaku pembunuhan yang tidak sengaja. Besarnya pembayaran denda sama dengan diyat berat. Tetapi dalam pelaksanaannya dibagi lima dengan rincian 20 ekor unta betina berumur 1 jalan 2 tahun, 20 ekor unta betina berumur 2 jalan 3 tahun, 20 ekor unta betina berumur 3 jalan 4 tahun, 20 ekor unta betina berumur 4 jalan 5 tahun dan 20 ekor unta betina berumur 5 jalan 6 tahun. Pelaksanaan denda dapat dibayarkan dalam jangka waktu 3 tahun dengan angsuran sepertiga dari jumlah dan dibayar setiap akhir tahun..
} 
membunuh seorang mukmin (yang lain), kecuali karena tersalah (tidak sengaja), dan barang siapa membunuh seorang mukmin karena tersalah (hendaklah) ia memerdekakan seorang hamba sahaya yang beriman serta membayar diyat yang diserahkan kepada keluarganya (yang terbunuh itu), kecuali jika mereka (keluarga terbunuh) bersedekah. Jika ia (si terbunuh) dari kaum (kafir) yang ada perjanjian (damai) antara mereka dengan kamu, maka memerdekakan hamba sahaya yang beriman. Barangsiapa yang tidak memperolehnya, maka hendaklah ia (si pembunuh) berpuasa dua bulan berturut-turut untuk penerimaan taubat daripada Alloh. Dan adalah Alloh Maha Mengetahui lagi Maha Bijaksana”). Surat An-Nisa ayat 92 telah membedakan antara hukuman pembunuhan yang tidak disengaja dengan pembunuhan yang dilakukan dengan sengaja. Hal ini disebabkan karena pembunuhan yang dilakukan dengan sengaja, pelakunya berniat melakukan maksiat. Oleh karena itu tindak pidana tersebut telah terhitung berat dan besar sesuai dengan beratnya hukuman yang diterimanya. Adapun pembunuhan yang dilakukan dengan tidak sengaja, pelakunya tidak berniat melakukan maksiat.

\section{B. Hukuman Bagi Komandan Yang Terbukti Bersalah}

Hampir seluruh Negara didunia mengakui tentang niat dalam suatu perbuatan. Asas universal dikenal dengan nama Dolus (kesengajaan) dan Culpa (kelalaian). Dolus adalah suatu kondisi psikologis yang ditujukan pada perbuatan atau tindakan itu, bilamana pelaku menginginkan perbuatan atau tindakan itu maka dikatakan ada kesengajaan, sebaliknya, bila ia sebenarnya tidak menginginkannya, namun tetap melakukannya padahal akibat yang tidak dikehendaki pembuat undang-undang dapat ia duga atau perhitungkan sebelumnya dan sebab itu juga dapat ia hindari dengan mudah, dapat dikatakan ia melakukannya dengan kelalaian. ${ }^{19}$

Sistem hukum Romawi pada mulanya hanya mengenal Dolus. Menghilangkan nyawa baik sengaja atau kelalaian tidak penting karena akan memunculkan hak balas dendam sehingga dikenal ungkapan Die tat totet den mann-le fait juge I'lhomme (tiap orang harus menanggung

\footnotetext{
${ }^{19}$ Jan Remmelink,Hukum Pidana, (Jakarta:PT Gramedia Pustaka Utama,2003). 149
} 
keonsekuensi dari perbuatannya). pemahaman tentang Culpa baru muncul kemudian dan doktrin yang selanjutnya berkembang memandang Dolus sebagai delik sebenarnya sedangkan Culpa dianggap delik semu. Hal ini berakibat pada sanksi hukum dimana delik Culpa hanya diancamkan dengan pidana ringan.

Dalam hukum pidana paling modern diabad ini khususnya dalam Statuta Roma tahun 1998 tidak menaruh respect pada unsur dolus dan culpa. Hal ini akan berakibat pada sanksi hukum yang akan dijatuhkan. Perumus Statuta sepertinya tidak ingin menutup kemungkinan bahwa orang yang perbuatannya memenuhi unsur-unsur pidana bisa bebas sekedar karena perbuatan tersebut tidak dapat dipersalahkan kepadanya. Namun Semestinya faktor niat tetap diperhitungkan dalam suatu perbuatan pidana.. Komandan yang tidak mengetahui tindak pidana yang dilakukan prajuritnya karena tidak berada ditempat, atau tidak akuratnya data sehingga salah informasi dan eksekusi, atau perintah yang dipersepsikan salah oleh prajuritnya sehingga terjadilah tindak pidana yang tidak diinginkan maka sudah seharusnya delik culpa berlaku terhadapnya. Apabila diberlakukan Hukum Pidana Islam dan agar tetap sesuai dengan tujuan Statuta “demi melindungi kepentingan masyarakat internasional” maka untuk komandan yang terkena delik culpa harus tetap bertanggungjawab atas perbuatannya yakni qisas namun terbuka peluang pemaafan dari seluruh keluarga korban. Perbuatan komandan yang menyuruh atau memerintahkan bawahannya untuk melakukan tindak pidana dalam Hukum Pidana Islam termasuk kategori “Turut Serta”, adapun pengertian turut serta dalam perbuatan pidana/Jinayah adalah melakukan perbuatan pidana/jinayat secara bersama-sama, baik melalui kesepakatan atau kebetulan, menghasut, menyuruh orang lain, memberi bantuan atau keluasan dengan berbagai bentuk. ${ }^{20}$ Turut Serta dalam Hukum Pidana Islam/Jinayah terbagi menjadi Turut Berbuat Langsung dan Turut Berbuat Tidak Langsung. Terhadap komandan yang menyuruh bawahan

${ }^{20}$ Rahmat hakim,Hukum Pidana Islam, (Bandung;CV Pustaka Setia,2000). 55 
melakukan tindak pidana maka perbuatan komandan ini termasuk kedalam “Turut Serta Berbuat Tidak Langsung”.

Menurut Ahmad Hanafi dalam Rahmat Hakim yang dimaksud dengan Turut Serta Tidak Langsung adalah setiap orang yang mengadakan perjanjian dengan orang lain untuk melakukan suatu perbuatan yang dapat dihukum atau menyuruh (menghasut) orang lain atau memberikan bantuan dengan disertai kesengajaan dalam kesepakatan dan menyuruh serta memberi bantuan.

Mengenai hukuman pelaku Turut Serta Tidak Langsung, menurut Hukum Pidana Islam adalah hukuman ta'zir ${ }^{21}$, dikarenakan Turut Serta Berbuat Tidak Langsung tidak ditentukan oleh Syara $^{22}$, baik bentuk maupun macam hukumnya. Jenis-jenis hukuman ta’zir tergantung pada keseriusan kejahatan dan cedera yang terjadi pada korban, sebuah kejahatan ta'zir serius dapat dihukum dengan hukuman mati. ${ }^{23}$

Mengenai komandan yang memerintahkan pasukan dibawah komandonya melakukan tindak pidana kemanusiaan seperti genocida yang tidak ada pengaturannya didalam Al-Quran dan As-Sunnah (yang diatur di dalam Al-Quran dan As-sunnah hanya pembunuhan biasa) jika berpegang pada pendapat Imam Maliki maka komandan tersebut dikenai hukuman qisas atau lebih berat atau sama berat dengan bawahannya. Pendapat penulis, untuk komandan yang memerintahkan tindak pidana genocida dihukum mati tanpa terbuka pemaafan. Alasan yang dapat dikemukakan bahwa tindak pidana genocida dapat dikategorikan kedalam tindak pidana hudud $^{24}$ yakni tindak pidana hirabah yang diperluas, dimana salah-satu unsur agar dapat

\footnotetext{
${ }^{21}$ Hukuman ini tidak ditentukan didalam Al-Quran dan As-sunah tetapi ditentukan berdasarkan kemaslahatan masyarakat yang selalu berkembang dan berubah. Dalam memberikan hukuman ini hakim diberi keleluasaan untuk berijtihad hukum apa yang hendak di jatuhkan kepada pelaku.

${ }^{22}$ Syara adalah (Al-Quran) yang memiliki sifat abadi dan sampai kapanpun akan dianggap sebagai kejahatan karena dianggap sebagai perbuatan maksiat.

${ }^{23}$ Paijah Haji Ismail dalam Mohd Hisham Mohd.Kamal,Hukum Humaniter Internasional (HHI) dan Al -Siyar Sebuah Kajian Perbandingan, (Jakarta;PT Serambi Ilmu Semesta,2015). 96

24 Hudud adalah hukuman bagi suatu tindak pidana yang menyangkut masyarakat banyak dalam arti kata mengganggu kepentingan, ketentraman dan ketertiban masyarakat. Karena hak masyarakat telah terganggu maka tindak pidana hudud ini menjadi hak Tuhan, hukuman yang dikenakan kepadanya bersifat pasti dan tiada pemaafan. Adapun tindak pidana hudud menurut ulama ada tujuh macam yaitu zina, menuduh berzina (qadzaf), minum-
} 
dikatakan sebagai hirabah adalah kekerasan atau ancaman kekerasan yang berdampak psikologis bagi korban sehingga menimbulkan trauma dalam jangka waktu yang panjang bahkan seumur hidup. Karena tindak pidana genocida termasuk kategori hirabah yang diperluas maka jenis hukumannya adalah hudud yang tidak memberi peluang pemaafan karena berkaitan dengan kepentingan, ketertiban dan keamanan masyarakat dan hukuman yang dijatuhkan adalah qisas (mati) karena pada intinya tindak pidana genocida adalah pembunuhan. Keluarga korban tidak memiliki hak untuk mengampuni pelaku. ${ }^{25}$ Sebagai perbandingan, dalam Statuta Roma tahun 1998 tidak mengenal hukuman mati. Hukuman tertinggi adalah pidana penjara paling lama 30 tahun atau penjara seumur hidup, denda, penebusan hasil kekayaan dan asset yang diperoleh langsung atau tidak langsung dari tindak pidana yang dilakukan. Hukuman-hukuman tersebut berdasarkan berat-ringannya tindak pidana ${ }^{26}$ (tidak disebutkan berat-ringannya tindak pidana berdasarkan dolus dan culpa)Mahmakah Pidana Internasional juga dapat mengurangi masa hukuman apabila seseorang telah menjalani dua pertiga dari hukumannya atau dua puluh lima tahun dalam hal hukuman seumur hidup jika orang tersebut bersedia bekerjasama dalam proses penyelidikan dan membantu mahkamah dalam kasus-kasus lain. ${ }^{27}$

Dalam hukum pidana umum, ketentuan tentang tentangmenggerakkan/membujuk orang lain untuk melakukan tindak pidana disebut Uitlokking. ${ }^{28}$ Ketentuan tentang tindak pidana

minuman keras (asyrib), pencurian (sariqah), pembegalan (hirabah), pemberontakan (al-baghyu) dan keluar dari agama islam (riddah).Dari ketujuh tindak pidana yang terkena hukuman hudud, salah-satu yang menurut penulis paling relevan bagi kejahatan genocida adalah hirabah (yang diperluas), Hal ini didasarkan pada pengertian dari hirabah yaitu perampokan yang dilakukan secara terang-terangan yang disertai dengan kekerasan atau ancaman kekerasan yang berdampak psikologis bagi korban sehingga menimbulkan trauma dalam jangka waktu yang panjang bahkan seumur hidup.

${ }^{25}$ untuk bawahan yang melakukan perintah atasan melakukan tindak pidana genosida dihukum qisas (mati) namun terbuka pemaafan jika (seluruh) keluarga korban menghendaki dapat mengampuni dan mengganti dengan denda seperti yang telah disebutkan diatas (pembayaran diyat hitungannya berlaku per satu orang, dengan kata lain 100 ekor unta/orang)

${ }^{26}$ Pasal 77 Statuta Roma Tahun 1998

${ }^{27}$ Pasal 110 Statuta Roma tahun 1998

${ }^{28}$ Uitlokking harus dibedakan dengan Doen Plegen yakni orang yang “menyuruh melakukan” dimana orang "yang disuruh" tidak mengetahui bahwa perintah tersebut merupakan tindak pidana. Doen Plegen tidak digunakan karena tindak pidana genocida merupakan tindak pidana luar biasa maka seseorang dianggap mengetahui dengan pasti bahwa perintah tersebut adalah perintah yang bertentangan dengan hukum. 
Uitlokking menyatakan bahwa siapa yang dengan pemberian atau janji-janji, penyalahgunaan kekuasaan/pengaruh, kekerasan, ancaman, tipu muslihat atau dengan cara memberi kesempatan, sarana atau informasi sengaja menganjurkan atau membujuk dilakukannya suatu tindak pidana akan dipidana sebagai pelaku tindak pidana. ${ }^{29}$ Menurut ayat 2 pasal 55 Kitab Undang-Undang Hukum Pidana (KUHP) pertanggung jawaban penggerak/pembujuk dibatasi hanya sampai apa yang dibujukkan untuk dilakukan itu serta akibatnya. Dalam hal unsur kekerasan, ancaman serta tipu muslihat tidak boleh demikian besarnya, sehingga orang yang digerakkan/dibujuk tidak punya pilihan lain selain melakukan perbuatan pidana tersebut atau sama sekali tidak menyadari bahwa perbuatannya adalah perbuatan pidana. Dalam Uitlokking orang yang digerakkan/ dibujuk bukanlah orang yang benar-benar tidak mengetahui apa yang dilakukannya serta akibat yang timbul dari perbuatan tersebut. Konsekuensi hukum yang timbul dari orang yang digerakkan/dibujuk adalah orang tersebut dapat dihukum sebagai orang yang melakukan (pleger). Namun demikian ancaman hukuman bagi orang yang menggerakkan/membujuk (Uitlokker) lebih berat sebagaimana yang telah ditetapkan dalam KUHP. ${ }^{30}$

Hal yang sama didalam Hukum Pidana Islam dan hukum pidana pada umumnya adalah tanggung jawab komandan terbatas pada apa yang ia perintahkan pada bawahan. Meskipun pekerjaan yang dilakukan bawahan-sesuai perintah komandan belum final, maka komandan bertanggungjawab sebatas pada yang telah dikerjakan bawahan demikian pula jika pekerjaan telah final, maka komandan bertanggungjawab pada seluruh perbuatan bawahan. Namun jika bawahan melakukan tidak sesuai yang diperintahkan maka komandan tidak bertanggungjawab pada apa yang dilakukan bawahan tersebut.

\footnotetext{
${ }^{29}$ Op.Cit,Jan Remmelink. 330

${ }^{30}$ Hukuman bagi orang yang digerakkan/dibujuk adalah hukuman pokok dikurangi sepertiganya.(ps 57 ayat 1KUHP), jika tindak pidana tersebut diancam hukuman mati atau seumur hidup maka dijatuhkanlah hukuman penjara selama-lamanya 15 tahun penjara (ps 57 ayat 2KUHP)
} 
Hal yang disebutkan diatas khususnya mengenai tindak pidana yang dilakukan bawahan diluar perintah komandan tidak diatur didalam Statuta Roma tahun 1998. Pasal 28 Statuta berprinsip "seharusnya mengetahui (should have known)”, maka tertutup kemungkinan bagi seorang komandan untuk lepas dari tuntutan terhadap perbuatan yangdilakukan bawahan yang bukan atas perintahnya. Sekali lagi, perumus statuta sepertinya tidak ingin menutup kemungkinan bahwa orang yang perbuatannya memenuhi unsur-unsur pidana bisa bebas sekedar karena perbuatan tersebut tidak dapat dipersalahkan kepadanya, namun upaya menetapkan orang yang sebetulnya tidak bertanggungjawab sebagai bertanggungjawab tidak sesuai dalam sistem hukum pidana universal.

\section{Penutup}

Hukum pidana umum mengatur bahwa seseorang bertanggungjawab atas segala perbuatannya dengan tetap memperhatikan unsur niat, dolus ataukah culpa. Dalam KUHP contoh unsur dolus dan culpa dapat dilihat dalam pasal 338 mengenai pembunuhan (konvensional) yang disengaja serta pasal 359 mengenai perbuatan mengakibatkan orang mati karena ketidaksengajaan/lalai. Didalam Statuta Roma tahun 1998 unsur dolus dan culpa tidak diperhitungkan hal ini tercermin dalam pasal 28 (a.1) dimana terdapat kata-kata "mengetahui atau seharusnya mengetahui” bahwa pasukannya melakukan tindak pidana. Hal ini berbeda dengan tanggung jawab atasan untuk sipil dalampasal 28 (b.1) yang hanya “mengetahui atau secara sadar tidak menghiraukan” informasi mengenai bawahannya yang melakukan tindak pidana. Dari kedua pasal tersebut tergambar bahwapasal 28 (a.1) telah mengeyampingkan unsur dolus dan culpa sementara pasal 28 (b.1) hanya untuk perbuatan yang disengaja artinya pasal ini tetap memperhatikan unsur dolus dan culpa sebagai unsur universal dalam hukum pidana.

Hukum Pidana Islam atau Jinayat memperhitungkan unsur niat didalam suatu tindak pidana sehingga berdasarkan niat tindak pidana terbagi tiga yaitu sengaja, semi sengaja (keliru) 
dan tidak sengaja (lalai.Pengakuan mengenai niat sebagai pertimbangan dalam penghukuman telah tercantum dalam surah An-Nisa ayat 92 dan 93.

Perbuatan komandan yang memerintahkan bawahan untuk melakukan tindak pidana genocida didalam Hukum Pidana Islam/Jinayat masuk dalam ketentuan mengenai “Turut Berbuat Tidak Langsung”. Tindak pidanagenocida termasuk kedalam tindak pidana hirabah (yang diperluas) yang mendapat hukuman hudud. Hudud adalah hukuman yang merupakan hak tuhan dan tidak terbuka pemaafan bagi pelaku (langsung maupun tidak langsung). Dikarenakan tindak pidana genocida adalah perbuatan membunuh maka hukuman bagi komandan adalah hukuman mati dan tidak terbuka pemaafan, sebagai perbandingan, Statuta Roma dalam pasal 77 tidak mengenal hukuman mati, yang diberlakukan adalah pidana penjara paling lama tiga puluh tahun atau penjara seumur hidup, denda, penebusan hasil kekayaan dan asset yang diperoleh secara langsung atau tidak langsung dari tindak pidana yang dilakukan. Berat ringannya hukuman tersebut berdasarkan berat-ringannya tindak pidana berdasarkan pasal 5 Statuta tanpa menyebutkan konsep mengenai dolus dan culpa.

Dalam Hukum Pidana Islam/Jinayat, hukuman bagi seorang komandan akan berbeda jika ternyataada unsur semi sengaja atau tidak sengaja (culpa) yakni dari hukuman mati tanpa pemaafan menjadi hukuman mati namun terbuka pemaafan jika seluruh keluarga korban menghendaki dengan membayar diyat/denda sebesar 100 ekor unta/korban (sama dengan pelaku). Namun jika bawahan terbukti melakukan tindak pidana genocida bukan berdasarkan perintah komandan maka komandan tidak bertanggungjawab terhadap perbuatan bawahan.

Hukum Pidana Islam/Jinayat memiliki nilai-nilai universal yang tidak berbeda dengan hukum pidana pada umumnya. Dalam penjatuhan sanksi terhadap suatu tindak pidana, Hukum Pidana Islam mempertimbangkan unsur kesengajaan dan kelalaian unsur ini juga dianut oleh sebagian besar Negara yakni dolus dan culpa. Statuta Roma tahun 1998 perlu 
mempertimbangkan unsur-unsur yang telah berlaku umum tersebut didalam pasal-pasalnya karena jika tidak maka penjatuhan sanksi akan menjadi tidak berkeadilan.

Statuta Roma tahun 1998 perlu mempertimbangkan hukuman mati karena si pelaku telah melakukan kejahatan sangat serius, bertindak sangat kejam bahkan mampu menggoyahkan perasaan kemanusiaan dan merupakan ancaman langsung terhadap perdamaian dan keamanan dunia (Direct threat to world peace and security and shocking to the conscience of humanity).Tidak ada balasan yang setimpal bagi tindak pidana genocida selain sanksi yang sama yang telah kejam dilakukan oleh pelakunya.

Hukuman mati adalah hukuman yang memberi rasa takut pada orang yang belum melakukan, memberi keadilan bagi keluarga korban, dapat memutus rantai sakit hati dan balas dendam dari keluarga korban dan demi kemaslahatan umum karena apabila dikenakan sanksi penjara maka banyak dana yang harus dikeluarkan mulai dari makanan sehari-hari, perawatan dan pengamanan gedung penjara hingga gaji petugas penjara yang mana dana tersebut seharusnya bisa dimanfaatkan untuk kemaslahatan umum lainnya. 


\section{DAFTAR PUSTAKA}

Atmasasmita,Romli, Pengantar Hukum Pidana Internasional, Jilid I, (Bandung: PT Refika Aditama,2003)

Atmasasmita,Romli,Pengantar Hukum Pidana Internasional Bagian II,(Jakarta; PT Hecca Mitra Utama,2004)

Djamali,Abdul, Hukum Islam, (Bandung; CV Mandar Maju,2002)

Hakim,Rahmat,Hukum Pidana Islam,Fiqih Jinayah,(Bandung,CV Pustaka Setia,2000)

Kelsen,Hans,Teori Tentang Hukum, (akarta: Konstitusi Pers,2012)

Lubis,Todung Mulya,Jalan Panjang Hak Asasi Manusia, (Jakarta:PT Gramedia Pustaka Utama,2005)

Mohd Hisham Mohd Kamal, Hukum Humaniter Internasional (HHI) dan Al-Siyar, sebuah kajian perbandingan,(Jakarta,PT Serambi Ilmu Semesta,2015)

Pangaribuan,Aristo M.A,Perdebatan Menuju Mahkamah Pidana Internasional (International Criminal Court), (Jakarta:Papas Sinar Sinanti dan FHUI,2013)

Parthiana,I Wayan,Hukum Pidana Internasional, (Bandung:CV Yrama Widya,2006)

Remmelink,Jan, Hukum Pidana,(Jakarta, PT Gramedia Pustaka Utama,2003)

Shaw QC,Malcolm,Hukum Internasional, (Bandung: Nusa Media,2013)

Atmasasmita,Romli, Karakteristik Tindak Pidana Dalam Statuta ICC Dan Dampak Pembentukan Pengadilan Pidana Internasional Terhadap Perkembangan Hukum Pidana, Jurnal Hukum Internasional, Volume 4, bulan Oktober 2006, Jakarta:Lembaga Pengkajian Hukum Internasional,Fakultas Hukum Universitas Indonesia,

Statuta Roma tahun 1998

Kitab Undang-Undang Hukum pidana (KUHP)

Undang-Undang No 26 tahun 2000 tentang Pengadilan Hak Asasi Manusia 